\title{
AKTIIVISEKSI KANSALAISEKSI KASVAMINEN SUOMALAISTEN ELÄMÄKERTOJEN VALOSSA
}

\author{
Aktiiviksi kansalaiseksi ei tulla lukemalla asiasta oppikirjoja, vaan siihen \\ "kouluttaudutaan" perinteisin tavoin, kasvamalla sellaiseksi malli- \\ oppimisen kautta. Aktiiviksi kansalaiseksi sosiaalistutaan varmimmin \\ seuraamalla lähietäisyydeltä ja jo lapsuudesta asti aktiivisten kansalais- \\ ten toimintaa ja osallistumalla siihen.
}

\section{MATTI LAITINEN JA KARI E. NURMI}

in association with Katariina Angeria, Esa

Heikkinen ja Tanja Khrol-Lappalainen irjoittajat ovat kolmen vuoden ajan osallistuneet EU:n viidennestä puiteohjel1 masta rahoitettuun Education and Training for Governance and Active Citizenship in Europe: Analysis of Adult Learning and Design of Formal, Non-Formal and Informal Education al Intervention Strategies (ETGACE) -tutkimukseen. Keskeisenä tutkimustehtävänä on ollut selvittää, miten aktiiviseksi kansalaiseksi kasvaminen tapahtuu osana elämänkulkua. Artikkelissa he tarkastelevat tätä kysymystä suomalaisen aineiston valossa.

\section{KANSALAISUUS}

Kansalaisuutta on pidetty kiistanalaisena ja vaikeasti määriteltävänä terminä (Benn 2000, 242, Lawson 2001, 1-2, Perczynski and Vink 2002, 184, Walters and Watters 2001, 473). Yleisesti hyväksyttyjä ovat olleet lähinnä vain Aristoteleen ja Marshallin klassiset määritelmät (Heater 1999, 44). Aristoteleen (335-323 / 1991, 63-64, vrt. myös Sihvola 1991) mukaan kansalaisia olivat ennen kaikkea ne, joilla oli mahdollisuus osallistua kaupunkivaltion neuvottelevien ja oikeudellisten virkojen hoitoon. Aristoteles siis erotti kansalaiset orjista ja siirtolaisista sekä lapsista ja naisista. Samoin ruumiillisen työn tekijät jäivät kansalaisuuden ideaalin ulkopuolelle. Toisin sanoen kansalaisilla tarkoitettiin vain niitä kaupunkivaltion miehiä, jotka ruumiillisesta työstä ja taloudellisista riippuvuuksista vapaina osallistuivat muiden kan- salaisten kanssa valtiovallan käyttöön (Harju 2002, 90).

Marshallin (1950) klassisen teorian mukaan kansalaisuudessa on ennen kaikkea kysymys siitä, että jokaista kohdellaan täysivaltaisena ja tasa-arvoisena yhteisön jäsenenä (Kymlicha 2002, 287). Tällainen jäsenyys toteutuu laajenevien kansalaisoikeuksien kautta. Siviilioikeudet muodostuvat henkilökohtaisesta vapaudesta, sananvapaudesta ja uskonnonvapaudesta, oikeudesta omistaa omaisuutta, solmia sopimuksia sekä oikeudesta turvautua lakiin ja oikeuslaitokseen. Poliittiset oikeudet liittyvät oikeuteen äänestää vaaleissa, asettua ehdokkaaksi ja tulla valituksi poliittisiin tehtäviin. Sosiaalisilla oikeuksilla taas tarkoitetaan taloudellisia, sosiaalisia ja sivistyksellisiä perusoikeuksia eli oikeutta kohtuulliseen sosiaaliseen turval-

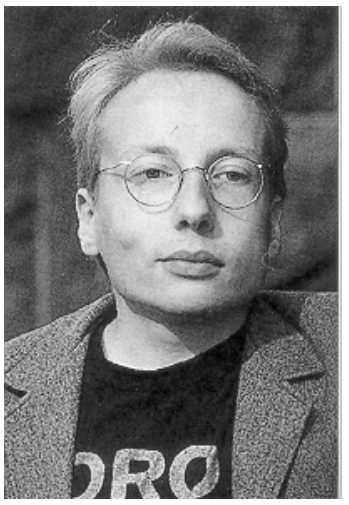

Matti Laitinen

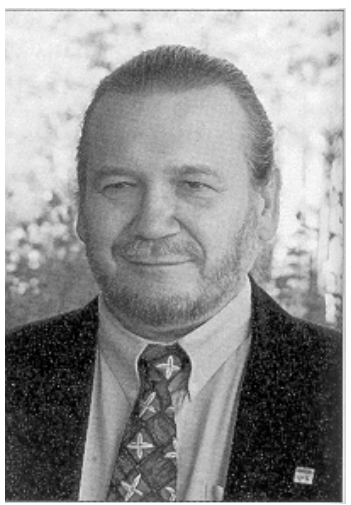

Kari E. Nurmi lisuuteen ja elintasoon. Marshallin (1950) kolmen elementin kansalaisuusteoriassa käänteentekevää on ollut sosiaalisten oikeuksien tuominen siviili- ja poliittisten oikeuk- 
sien rinnalle kansalaisuuden ytimeen (Jääskeläinen 2000, 117). Teoriassaan Marshall (1950) liittää sosiaalisten oikeuksien kehityksen kansalaisten osallistumismahdollisuuksien laajentamiseen, demokratian laajentamiseen. Marshallin (1950) mukaan luokkajaot eivät katoa yhteiskunnasta vain rahallisilla avustuksilla, vaan yhteiskunnan on taattava taloudelliset, sosiaaliset ja sivistykselliset oikeudet kaikille ja sitä kautta luotava edellytykset sille, että kansalaiset voivat myös ottaa vastuuta yhteiskunnan kehityksestä. (Koistinen 1999, 241). Toisaalta Marshallin (1950) näkemystä on kritisoitu 'passiiviseksi' tai 'yksityiseksi' kansalaisuudeksi, koska se korostaa yksipuolisesti kansalaisten oikeuksia ja jättää mainitsematta heidän velvollisuutensa osallistua 'julkiseen elämään'. On myös väitetty, että kansalaisoikeuksista nauttimisen lisäksi tai sijasta jatkossa tulisi kiinnittää enemmän huomiota kansalaisten vastuisiin ja velvollisuuksiin (Kymlicha 2002, 288).

Korsgaard $(2001,67)$ on kiteyttänyt kansalaisuudesta käytyä keskustelua sanomalla, että kansalaisuus merkitsee aina kahta elementtiä: kansalaisuus on sekä status että rooli. Korsgaardin mukaan kansalaisuus statuksena perustuu juridiselle tulkinnalle kun taas kansalaisuus roolina pohjautuu lähinnä 'kulttuurilliselle tunteelle' tai kansalaisidentiteetille. Delanty (2000, 9-11) puolestaan on todennut, että kansalaisuus tarkoittaa laajimmassa merkityksessään ryhmän jäsenyyttä. Jos asia halutaan ilmaista tarkemmin, kyseessä on nimenomaan poliittisen yhteisön jäsenyys. Kansalaisuus poliittisen yhteisön jäsenyytenä koostuu oikeuksista, velvollisuuksista, osallistumisesta ja identiteetistä, joita voidaan kutsua myös kansalaisuuden elementeiksi tai ryhmän jäsenyyttä määritteleviksi periaatteiksi.

Esitettyihin määritelmiin on kuitenkin suhtauduttava tietyllä varauksella. 1990-luvun lopun ja 2000-luvun kansalaisuuskeskustelussa on korostettu lisääntyvässä määrin sitä, että kansalaisvaltion tai muun poliittisen yhteisön jäsenyys on joillekin ryhmille helpommin saavutettavissa kuin joillekin toisille (Yuval-Davis 1997, 24) ja että kansalaisuus on loppujen lopuksi vain abstraktio, johon yksilöt suhteutuvat erojen kautta (Gordon ja Lahelma 1998, 252). Vaikka naiset ovat useimmissa länsimaissa saaneet samat poliittiset oikeudet kuin miehet, tilanne Suomessakin osoittaa, että naiset ja miehet ovat kansalaisina hyvin eriarvoisessa asemassa. Myös vähemmistöjen ase- maa luonnehtii usein jonkin asteinen vajaavaltaisuus (Lappalainen 2002, 221) tai toisen luokan kansalaisuus (Barnes, Mercer ja Shakespeare 1999, 41-42).

Miksi kansalaisuudesta on viime vuosina tullut niin suosittu käsite? Kymlicha (2002, 284-285) on eritellyt kansalaisuuteen kohdistuvan lisääntyneen kiinnostuksen taustalla olevia tekijöitä. Ensinnäkin kansalaisuus on tarjonnut integroivan ja välittävän käsitteen liberalististen ja kommunitarististen näkökulmien edustajien väliselle keskustelulle. Kansalaisuushan liittyy yhtäältä liberalistisiin ideoihin yksilön oikeuksista ja velvollisuuksista sekä toisaalta kommunitaristisiin ajatuksiin yhteisön jäsenyydestä ja ihmisten liittymisestä johonkin yhteisöön. Toiseksi useat maailmanlaajuiset kehityskulut ja tapahtumat kuten lisääntynyt äänestämättä jättäminen, pitkäkestoinen riippuvaisuus sosiaaliavustuksista Yhdysvalloissa, kansallismielisten ääriliikkeiden elpyminen Itä-Euroopan maissa, erilaiset monikulttuurisuuden kasvun aiheuttamat paineet Länsi-Euroopassa sekä hyökkäykset hyvinvointivaltiota vastaan Thatcherin Englannissa, kansalaisten vapaaehtoiseen yhteistyöhön perustuvien ympäristön suojelullisten poliittisten pyrkimysten epäonnistuminen, tyytymättömyys globalisaation vaikutuksia kohtaan ja koettu kansallisen itsemääräämisoikeuden katoaminen ovat tehneet selväksi, että modernin demokratian hyvinvointi ja vakaus eivät riipu vain instituutioiden oikeudenmukaisuudesta vaan myös kansalaisten 'laatu-ominaisuuksista' ja asenteista. Toisin sanoen, demokratia on riippuvainen esimerkiksi kansalaisten aktiivisuudesta eli muun muassa siitä, ovatko he halukkaita osallistumaan poliittisiin prosesseihin yhteisen hyvän edistämiseksi ja poliittisten auktoriteettien pitämiseksi vastuullisina.

\section{AKTIIVINEN KANSALAISUUS}

Se tosiasia, ettei kansalaisuudelle ole löydetty yhtä yleisesti hyväksyttyä määritelmää on vaikuttanut siihen, että myös se mitä tarkoitetaan aktiivisella kansalaisuudella vaihtelee suuresti. Lähtökohtana on kuitenkin tavallisesti ollut, että aktiiviset kansalaiset edistävät jotain yhteistä hyvää tai toimivat jonkin yhteisen asian hyväksi. Suomalaisessa kontekstissa aktiivinen kansalaisuus on viime vuosina tarkoittanut esimerkiksi ympäristöasioiden ajamista, globalisaation vastustamista ja lähiökirjaston puolustamista, toi- 
saalta aktiivista kansalaisuutta ovat ilmentäneet myös työttömien järjestötoiminta, perinteinen rauhantyö tai ihmisoikeusaktivismi (Harju 2002, 102).

Aktiivista kansalaisuutta on luonnehdittu toiminnaksi, jolle on ominaista kriittisyys ja kyseenalaistava suhtautuminen vallitseviin olosuhteisiin sekä tarvittaessa suora toiminta asioiden muuttamiseksi (Harju 2002, 102). Esimerkiksi Crick (2000, 2-3) on todennut, että aktiiviset kansalaiset ovat "halukkaita, osaavia ja valmiita vaikuttamaan julkisessa elämässä ja heillä on kriittisyyttä ja kykyä punnita asioita ennen kuin puhuvat ja toimivat". Myös Jarvis $(2002,25-26)$ on korostanut asioista perillä olevan aktiivisen kansalaisuuden merkitystä, jotta "inhimillisyyttä ja ekosysteemiä uhkaavien riskien globaalit aiheuttajat ja heidän tukijansa niin tieteessä kuin politiikassakin voitaisiin saada vastuuseen ja jotta vastarinnan politiikalla voisi olla merkitystä”. Periaatteessa tämä edellyttää, että aktiivisilla kansalaisilla pitäisi olla vähintään saman tasoinen tietämys kuin edellä mainittujen riskien aiheuttajilla. Aktiivinen kansalaisuus ei siis edellytä vain järjestöjen ja kansalaisliikkeiden jäsenyyttä, vaan myös ymmärrystä ja opiskelua, jotta voitaisiin toimia ja vaikuttaa tehokkaasti. Jarvis $(2002,26)$ korostaa dialogin merkitystä, mutta ei sulje toisaalta pois myöskään mielenosoituksia yhtenä vaikuttamisen keinona.

Aktiivisen kansalaisuuden on lisäksi sanottu edellyttävän (1) kykyä neuvotella ja tehdä yhteistyötä toisten kanssa, kohdata erilaisuutta ja käsitellä konflikteja, kuunnella rakentavasti toisia, hankkia informaatiota ja ilmaista ajatuksia sekä mielipiteitä, (2) itseluottamusta toimia ennakoivasti, pitää kiinni omista mielipiteistään, toimia itsenäisesti, jos he ajattelevat, että se on oikein, ottaa vastuuta, uskoa siihen, että heidän mielipiteensä kuullaan ja otetaan huomioon ja (3) tietoa siitä, kuinka yhteiskunta on organisoitu, kuinka paikallishallinto ja kansallinen hallinto toimivat ja mitkä ovat tärkeimpien puolueiden pääajatukset sekä, mitä poliittisia filosofioita/ideologioita on. (Benn 2000, 245.)

Euroopan unioni lanseerasi aktiivinen kansalaisuus -käsitteen eurooppalaisella ulottuvuudella vuonna 1997 asiakirjalla DG XXII Citizenship study (Harju 2002, 99). Myös usein siteeratussa Euroopan Unionin vuoden 2000 elinikäisen oppimisen muistiossa määritellään aktiivinen kansalaisuus. Muistion mukaan kansalaiset "voivat osallistua kulttuuriseen, taloudelliseen, poliittiseen ja sosiaaliseen elämään niin täydesti kuin mahdollista" sekä "ottaa omien yhteisöjensä tulevaisuuden muotoileminen omiin käsiinsä ja tulla oman elämänsä arkkitehdeiksi ja toimijoiksi" (Benn 2000, 243, Bron 2001, 138, Korsgaard 2002 ).

Aktiiviseen kansalaisuuteen on myös pyritty liittämään merkityksiä, jotka eivät siihen kuulu. Esimerkiksi thatcherismin kontekstissa aktiivisesta kansalaisuudesta puhuminen ilmensi halua supistaa julkista sektoria ja poliittisesti velvoittaa ihmisiä vastaamaan itse itsestään (Lawson 2002, 166-167). Kuten jo aiemmin todettiin aktiivisen kansalaisen -käsite merkitsee kuitenkin aivan muuta: vaikuttamista ja toimimista jonkin yhteisen asian hyväksi.

\section{ELÄMÄKERTATUTKIMUKSEN AINEISTO JA TOTEUTUS}

Tässä artikkelissa esiteltävä kuvaus aktiiviseksi kansalaiseksi kasvamisesta perustuu Education and Training for Governance and Active Citizenship in Europe: Analysis of Adult Learning and Design of Formal, Non-Formal and Informal Educational Intervention Strategies (ETGA$C E)$-tutkimuksen puitteissa kerättyn elämäkertatutkimuksen (Laitinen ja Nurmi 2002) aineistoon. Jokaisessa tutkimukseen osallistuvassa kuudessa maassa (Alankomaat, Belgia, Englanti, Espanja, Slovenia ja Suomi) tehtiin 16 aktiivisen kansalaisen elämäkertahaastattelut eli yhteensä projektissa tehtiin 96 haastattelua. Haastateltujen valinnassa huomioitiin seuraavat kriteerit: (1) puolet haastateltavista oli naisia, puolet miehiä, (2) he jakaantuivat kahteen ikäkohorttiin (25-40-vuotiaat ja 55-70-vuotiaat) ja (3) he toimivat aktiivisina kansalaisina erilaisissa konteksteissa (esimerkiksi työelämässä, politiikassa, kansalaisyhteiskunnassa ja perheen parissa). Suomessa päätettiin näiden kriteerien lisäksi valita puolet haastatelluista etelästä, ja puolet pohjoisesta tai ainakin muualta kuin pääkaupunkiseudulta.

Haastateltavien valinta tapahtui jokaisessa tutkimukseen osallistuvassa maassa kansallisten neuvoa antavien asiantuntijaryhmien tuella. Tutkimuksen suomalaisen asiantuntijaryhmän ${ }^{1}$ jäseninä toimivat Reijo Aholainen opetusministeriöstä, Erkki Auvinen STTK:sta, Riitta Jalonen Yleisradiosta, Antti Kauppi Helsingin ammatillisesta opettajakorkeakoulusta, Paula Kyrö Tampereen yliopistosta, Timo Luopajärvi Helsingin ammat- 
tikorkeakoulusta, Eeva-Inkeri Sirelius Kansalaisja työväenopistojen liitosta, Marja-Terttu Tanttinen Metalliteollisuuden keskusliitosta, Timo Toiviainen Vapaan Sivistystyön Yhteisjärjestöstä sekä Pentti Yrjölä opetushallituksesta. Tutkijat pyysivät heitä nimeämään henkilöitä, joita he pitivät aktiivisina kansalaisina eli esittämään ostensiivisen määritelmän, mitä aktiivisella kansalaisuudella Suomen kontekstissa tarkoitetaan. Tämän jälkeen tutkijat poimivat haastateltavat (taulukko 1) asiantuntijaryhmän konstruoimalta listalta ottaen huomioon edellä mainitut valintakriteerit.

Kaksiosaiset elämäkertahaastattelut toteutettiin talven 2000-2001 kuluessa. Ensimmäisellä haastattelukerralla haastateltuja pyydettiin kertomaan vapaamuotoisesti oma elämäntarinansa. Toista haastattelukertaa varten tutkijat litteroivat ensimmäisen haastattelun aineiston sekä kirjoittivat ensimmäiseen haastatteluun perustuvan tiivistelmän eli 2-3 sivun mittaisen kuvauksen elämäkerran yleisestä kulusta. Toisen haastattelukerran aluksi haastateltavat korjasivat ja täydensivät tiivistelmää, minkä jälkeen keskityttiin tarkastelemaan niitä elämänkulun vaiheita, jotka olivat olleet merkityksellisiä tai käänteentekeviä aktiivisen kansalaisuuden oppimisen kannalta. Toisen haastattelun aineisto litteroitiin ja tiivistelmästä kirjoitettiin uusi versio, joka sisälsi haastatellun tekemät korjaukset sekä aktiivisen kansalaisuuden oppimiseen liittyvät asiat. Varsinainen analyysi perustui puhtaaksikirjoitettuihin elämäkerta-aineistojen litteraatteihin, joita luettiin sekä yksin että joidenkin elämäkertojen osalta myös yhdessä keskustellen. Kysymys oli ainakin jossain mielessä hermeneuttisesta prosessista tai syklistä, jonka kuluessa aineistoa pyrittiin jatkuvasti ymmärtämään ja tulkitsemaan uudelleen (Celis, Snick, Stroobants ja Wildemeersch 2001, 10, Goodson ja Sikes 2001, 34-35).

Elämäkertatutkimusta ei voi raportoida kertomatta mitään haastateltujen elämästä. Tästä syystä haastatelluille selitettiin jo tutkimuksen alkaessa, että joku - ainakin haastatellun puoliso voi tunnistaa asianomaisen aikanaan kirjoitettavista tutkimusraporteista. Sovittiin myös, että he saavat lukea etukäteen, mitä heistä tullaan julkaisemaan. Haastatelluista käytetään keksittyjä etunimiä paitsi silloin, kun he ovat yleisesti tunnettuja ns. julkisuuden henkilöitä. Heidän osaltaan ei ole katsottu järkeväksi käyttää salanimiä, koska heidät kuitenkin tunnistettaisiin. Näiden ns. julkisuuden henkilöiden kanssa on keskusteltu oikeiden etunimien käytöstä ja he ovat hyväksyneet menettelyn.

\section{AKTIIVISEKSI KANSALAISEKSI ELÄMÄKERTOJEN VALOSSA}

Suomalaisessa elämäkerta-aineistossa korostui kodin ja varhaissosialisaation merkitys. Perusarvot ja mielen perusrakenteet omaksuttiin lapsuuden ja nuoruuden aikana. Varhainen oppiminen näkyi jollain tavalla kaikessa myöhemmässä elämässä. Tämä ei tarkoita sitä, että haastatellut olisivat vain toistaneet lapsuudenkodin kokemuksia, vaan he olivat myös kapinoineet niitä vastaan. Lähes kaikki haastatellut 'selittivät' myös itse aktiiviseksi kansalaiseksi tuloaan kodin vaikutuksella. Osa heistä viittasi lisäksi johonkin tiettyyn asiaan, johon kaikki ikään kuin kulminoitui. Seuraavassa lainauksessa Esko kertoo isästään, joka oli seppä sekä siitä, kuinka kylän miehet tulivat hänen isänsä pajalle ja muodostivat siellä eräänlaisen poliittisen keskustelun foorumin.

”...se oli just tätä keskustelevaa aktiivisuutta sitte, että isä oli seppä ja tuota sen takiahan se, siinähän se oliki just aika paljon, just tämä vanha tämmönen käsityöläisammatti, katokko tuota nehän isännät tuota tulit sinne pajaan ja se oli sitte just semmonen kohtaamispaikka ja sitte niitä tuli niitä isäntiä koko pitäjän alueelta ja muuta vastaavaa, että siinä kulki se, se oli hyvin paljon semmosta niinkun tiedon, se oli tavallaan niinku televisio, jossa olit sekä poliittiset ohjelmat että tuota uutiset, että ne tapahtu siinä ahdon ympärillä ja sitte taas kyläläiset saatto tulla, niinko ennen käytiin kylässä taikka näin, että se kylässä käyminenhän ei ollu sitä, että tultiin, vaan että sitä tultiin vaan, että joku ilmesty siihen ja se alko tämä inttäminen sitte ja se saatto, ja sillä oli tarve tulla niinkun se oli vaikkapa lehessä lukenu jotaki semmosta, joka tuota aatteli, että tuon hän haluaa mennä sanomaan sille ja panemaan sen kato koville ja niin edelleen. (haastateltu nauraa) Ja puolin ja toisin sitte." (Eskon ensimmäinen haastattelu)

Esko kertoo myöhemmin ikään kuin toistaneensa tätä 'inttämisen mallia' omassa poliittisessa ja hallinnollisessa työssään, ja käyttää tarinaa selityksenä myöhemmille onnistumisilleen elä- 


\begin{tabular}{|c|c|c|c|c|}
\hline \multicolumn{3}{|c|}{ KRITEERI } & NIMI & BIOGRAFIA \& AKTIIVISUUDEN KONTEKSTI \\
\hline \multirow{4}{*}{ 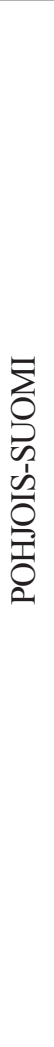 } & \multirow[b]{2}{*}{ 至 } & $55-70$ & Helvi & $\begin{array}{l}\text { - työskentelee ammatillisessa oppilaitoksessa. Hän on jäsenenä use- } \\
\text { assa järjestössä, kuten Martoissa, ja hän on taistellut useiden sosi- } \\
\text { aalisten asioiden puolesta } \\
\text { - usean alan aktiivinen kansalainen, jolla monipuolinen kokemus } \\
\text { osallistavasta sosiaalityöstä ja paikallisesta kampanjoinnista }\end{array}$ \\
\hline & & $25-44$ & Katja & $\begin{array}{l}\text { - poliittisesti aktiivinen opiskelija. Hänellä on kokemusta sekä kou- } \\
\text { luun liittyvistä että muista järjestöistä. Hän on aktiivinen myös ur- } \\
\text { heilussa ja hänellä on oma kansainvälinen verkosto } \\
\text { • kasvatustieteen maisteri, joka toimi aiemmin opettajana. Hän on } \\
\text { aktiivinen useissa asioissa, jotka liittyvät etnisesti tai kulttuurisesti } \\
\text { saamelaisten asioihin tai porotalouteen yhtä hyvin kun taiteeseen ja } \\
\text { turismiin liittyvissä asioissa. }\end{array}$ \\
\hline & \multirow{2}{*}{ 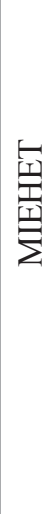 } & $55-70$ & Veikko & $\begin{array}{l}\text { - professori ja rehtori Lapin yliopistossa. Hän on myös aktiivinen } \\
\text { kunnallispolitiikko, kristillis-yhteiskunnallisen työkeskus Rovalan hal- } \\
\text { lituksen puheenjohtaja ja urheiluvaikuttaja. } \\
\text { • toimii Lapin liiton edunvalvontapäällikkönä. Hän on mukana va- } \\
\text { semmistoliiton toiminnassa sekä urheilu- ja muissa järjestöissä. }\end{array}$ \\
\hline & & $25-40$ & Hannu & $\begin{array}{l}\text { - keskustapuolueen kansanedustaja, joka on valmistunut yliopis- } \\
\text { tosta luokanopettajaksi, aktiivinen nuorisoasioissa ja hänellä on lu- } \\
\text { kuisia kansainvälisiä kontakteja erityisesti Israeliin } \\
\text { - yliopistossa opiskeleva kunnallispoliitikko ja vammaisaktivisti. Hä- } \\
\text { net vapautettiin teini-iässä oppivelvollisuudesta. Hän suoritti kou- } \\
\text { lun loppuun aikuisiällä ja jatkoi opiskelua ensin lukiossa ja myöhem- } \\
\text { min yliopistossa. }\end{array}$ \\
\hline \multirow{4}{*}{ 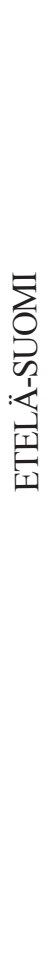 } & \multirow{2}{*}{ 至 } & $55-70$ & $\begin{array}{l}\text { Leena } \\
\text { Marjaa- } \\
\text { na }\end{array}$ & $\begin{array}{l}\text { - kansalaisopiston opettaja, aktiivinen useissa erityisesti elinikäi- } \\
\text { sen oppimiseen liittyvissä järjestöissä } \\
\text { - osastosihteeri, toiminut aktiivisesti mm. sotilaskotitoiminnassa. } \\
\text { Huolehti ikääntyvistä vanhemmistaan, oli mukana perustamassa ryh- } \\
\text { mää vanhusten aseman parantamiseksi. Huolissaan perheiden hyvin- } \\
\text { voinnista. }\end{array}$ \\
\hline & & $25-44$ & $\begin{array}{l}\text { Anne } \\
\text { Kirsi }\end{array}$ & $\begin{array}{l}\text { - yliopistossa opiskeleva maanviljelijä, joka oli mukana perustamassa } \\
\text { nuorten maanviljelijöiden toimintaryhmää } \\
\text { • ympäristökasvattaja, maa- ja metsätaloustieteen maisteri, toiminut } \\
\text { aktiivisesti ympäristönsuojelujärjestöissä, kiinnostunut erityisesti } \\
\text { metsien suojelusta }\end{array}$ \\
\hline & \multirow[t]{2}{*}{ 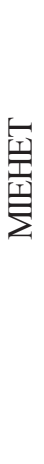 } & $55-70$ & Martti & $\begin{array}{l}\text { - eläkkeellä oleva osastopäällikkö, aktiivinen useissa järjestöissä. } \\
\text { Käynnisti työurallaan useita uraauurtavia hankkeita opetusteknolo- } \\
\text { gian kaupan alalla. Nyt aktiivinen kirjoittaja: muistelmia, runoja jne. } \\
\text { Opastaa ja tukee muita eläkeläisiä näiden kirjallisissa harrastuksissa } \\
\text { ja opinnoissa } \\
\text { - entinen ammattiyhdistysaktiivi, joka toimii tällä hetkellä työttömi- } \\
\text { en yhdistyksen johdossa }\end{array}$ \\
\hline & & $25-44$ & $\begin{array}{l}\text { Jyrki } \\
\text { Oiva }\end{array}$ & $\begin{array}{l}\text { - vihreä nettipoliitikko. Osallistuu yhteiskunnalliseen keskusteluun } \\
\text { myös kirjoittajana ja tutkijana. } \\
\text { • yksi avainhenkilöistä nuorisokahvila idean takana. Luennoi ja } \\
\text { tekee vapaaehtoistyötä nuorten parissa }\end{array}$ \\
\hline
\end{tabular}


mässä ja politiikassa onnistumisille asioissa, joita useimmat muut eivät olisi edes yrittäneet tavoitella kuten esimerkiksi yliopiston perustamista Lappiin.

Aineiston perusteella on myös ilmeistä, että aktiiviseksi kansalaiseksi tulemisen takana on lukuisia valintoja. Esimerkiksi Jyrkin tulo Suomen ensimmäiseksi nettipoliitikoksi näyttää lähes vääjäämättömältä seuraukselta hänen aiemmista elämänvalinnoistaan: tietotekniikan lukeminen valinnaisena aineena lukiossa, tietokonepelien ohjelmoimisen ja niistä kirjoittamisen aloittaminen, opiskeleminen teknillisessä korkeakoulussa, Nokian lehden 'Softarin' toimittaminen, tutkimustyö tietokoneavusteisen työnopastuksen kehittämisessä jne. Seuraavassa lainauksessa Jyrki kertoo, kuinka hän päätti ostaa levysoittimen sijasta tietokoneen kesätöistä saaduilla ansioillaan sekä toteaa tämän päätöksen olleen yksi hänen elämänsä tärkeimmistä ratkaisuista.

"Joo ja sitten tosiaan, kun minä tein kesätöitä sitten kunnalle, minä ajoin, leikkasin nurmikoita, niin sitten minulla oli kaksi vaihtoehtoa sillä rahalla minä saatoin saada. Joko minä saatoin ostaa itselleni uuden tangentiaalilevysoittimen, olin vähän hifi-harrastajaa silloin, tai sitten minä saatoin ostaa itselleni Vic-20:sen, ja tämä oli kova valinta ja se kääntyi tähän kaksikymppisen suuntaan lopulta. Minä olen monta kertaa miettinyt, että tämä oli yksi tärkeimpiä valintoja, mitä minä olen tehnyt elämässäni." (Jyrkin ensimmäinen haastattelu)

Toisaalta aktiiviseksi kansalaiseksi tuleminen näytti - ainakin aineiston pintatason analyysin perusteella - noudattavan myös eräänlaista duaalimallia. Yhtäältä, osa haastatelluista oli ollut aktiivisia kansalaisia nuoruudesta ja jopa lapsuudesta lähtien. Marjaanan elämäkerta noudatti tätä mallia. Seuraavassa lainauksessa hän kertoo, kuinka hän lähti auttamaan sotilaskotiyhdistyksessä vapaaehtoistyötä tekevää äitiään ja liukui lähes huomaamattaan mukaan toimintaan.

"Äiti oli silloin ottanut kirjastonhoidollisen vastuun, ja minä olin siinä tavallaan mukana lainaamassa ja leimaamassa niitä kirjoja. Ja hän sitten huolehti siitä, että kun niitä uusia tulevia kirjoja laitettiin hyllyihin, niin hän laittoi ne luokkajärjestyksiin ja tämän tyyppistä hommaa teki siinä. Ja sitten, kun tilaisuuksia oli, niin aivan samalla lailla oli kaa- tamassa kahvia ja kun tilaisuudet oli takanapäin, niin osallistuttiin kimpassa tiskaukseen ja korjattiin pois, ja tämän tyyppistä hommaa, mitä nyt sitten vielä tänä päivänäkin tehdään, että sen on oppinut siellä." (Marjaanan toinen haastattelu)

Toisaalta, osa haastateltavista näytti tulleen aktiivisiksi kansalaisiksi vasta aikuisiällä. Vaikka useat olivat tässäkin ryhmässä toimineet nuoruudessaan esimerkiksi nuorisokerhojen ohjaajina tai rippikoulujen isoisina sekä olleet kiinnostuneita yhteiskunnallisesta vaikuttamisesta, tämä ei ollut välittömästi johtanut heitä aktiivisen kansalaisen uralle, eikä heidän aikuisiän aktivoitumisensa muutenkaan vaikuttanut itsestään selvältä. Näytti pikemminkin siltä, että he olisivat myös voineet olla aktivoitumatta ilman jotain tiettyjä kokemuksia tai olosuhteiden muuttumista. Esimerkiksi Annen kohdalla aktiiviseksi kansalaiseksi tulo liittyi ensi vaiheessa ainakin osittain pienten lasten äidin yksinäisyyden tunteeseen. Myöhemmin toiminnan ensisijaiseksi moottoriksi tuli tarve reagoida Euroopan Unioniin liittymisen maataloudelle aiheuttamiin haasteisiin. Seuraavissa lainauksissa Anne kertoo ensin lähdöstään mukaan MTK:n nuorten tuottajien toimintaan. Tämän jälkeen hän kuvaa niitä tekijöitä, jotka olivat esimerkiksi maanviljelijöiden toimintaryhmän, 'Alkuvoiman' perustamisen taustalla.

”Ja, tuota läksin sen takia, että ensinnäkin, mulla ei ollut ketään kavereita siellä kotikulmilla. Kaikki koulukaverit oli häipyneet..." (Annen toinen haastattelu)

"Ja tähän sitten liittyi sillä lailla meidän perheessäkin tällaiset pohdinnat, että mitäs nyt. Meillä on kuitenkin kolme lasta elätettävänä ja halutaan se koti säilyttää. Kun meidän tilan myytävien tuotteiden hinta yhdessä yössä tippui 60 prosenttia, vaikkakin siihen liittyi tällaisia siirtymävaihetukia, niin kuitenkin se kustannusrakenteen muutos oli niin totaalinen, että ei niin kuin voinut jäädä vain paikalleen." (Annen toinen haastattelu)

Elämäkerta-aineiston perusteella näyttää siltä, että koulujen opetus ja oppisisällöt vaikuttavat vain vähän aktiivisen kansalaisuuden syntyyn ja vakiintumiseen. Vaikka koulun välittämä tietovaranto on välttämätön, se ei itsessään herätä eikä ylläpidä aktiivisuutta. Seuraavassa lainauksessa Kirsi kertoo omista koulukokemuksistaan. 
"...mulle opetettiin koulussa, että Suomen yhteiskunta on valmis ja hyvä ja hyvässä järjestyksessä ja meillä on hallintajärjestelmä joka pyörittää tätä juttua. Mä en kerta kaikkia ymmärrä, miten sen opetuksen perusteella kukaan ois voinut kokea, et sen tarvitsee mennä politiikkaan. Eli että opettaa täysin erilainen kuva niin kun todellinen kuva yhteiskunnasta eikä mikään 'täällä on vallan kolmijako' ja kaikkea muuta paskaa. No sit kun nää on olemassa niin sen jälkeen koulussa voitaisiin konkreettisesti ottaa tämmöisiä yhteiskuntaan vaikuttamiskursseja, yhteiskuntaopetuksen pohjaksi: ihan selkeästi opettaa sitä, että sä voit ruveta puuttumaan asioihin heti, eikä sitten kun sulla on loppututkinto." (Kirsin toinen haastattelu)

Jos Kirsin sanomaa hieman kärjistetään, kansalaistaitoja ei hänen mielestään opeteltu niinkään elämää kuin koulua varten. Opiskelun ensisijaisena tavoitteena oli valmistaa oppilaita vastaamaan oikein erilaisissa kokeissa kuten ylioppilaskirjoituksissa. Tarkoituksena ei ollut kehittää jokapäiväisessä elämässä tarvittavia perusvalmiuksia puhumattakaan siitä, että olisi innostettu oppilaita osallistumaan yhteiskunnalliseen päätöksentekoon.

Vaikka haastatellut korostivat, että kansalaistoiminnassa tarvittavia tietoja ja taitoja omaksuttiin ennen kaikkea käytännön toiminnan kautta, aineistosta noussut ilmeinen tekijä oli, aivan nuorempia lukuun ottamatta haastateltujen toistuva tarttuminen tarjolla olleisiin oppimismahdollisuuksiin kuten esimerkiksi vapaan sivistystyön (opintokerhot, aiemmin opintopiirit, aikuiskoulutuskeskusten kurssit) tarjontaan. Seuraavassa lainauksessa Eero kertoo saksan kielen opiskelustaan.

”... mä olin yhtenä kesänä kesäyliopistossa saksaa opiskelemassa, mä mainitsinkin sen tuossa liitteessä, sitä kautta niinku yritin kielitaitoa kehittää, koska peruskoulutuksessa on, se jäi kyllä niin huonolle. Se kun aikanaan oli niin lyhyet kouluvuodet siinä ei ehtinyt paljon, muutoinkin oli levotonta, niin ei silloin voinut keskittyä koulutyöhön oikein ja sillä lailla. Ja sit on jääty vielä niin ku .. no ruotsi mulla oli niin ku vahva jo alusta asti, sen kanssa mä käytännössä pärjäsin hyvin. Saksaa joutui sitten opiskelemaan ja ennen kaikkea käytännön kielitaidon saavuttami- nen, siinä meni muutama vuosi." (Eeron toinen haastattelu)

Eeron tapaan haastateltujen opiskelu ei läheskään aina liittynyt suoraan sen hetkiseen tai edes tulossa olevaan kansalaisaktiivisuuteen, vaan oli pikemminkin kesken jääneen koulutuksen täydentämistä, yleissivistävää tai henkilökohtaisiin harrastuksiin liittyvää. On kuitenkin ilmeistä, että opiskelun myötä hankitusta osaamisesta kuten kielitaidosta oli hyötyä myös aktiivisen kansalaisen uralla, vaikka haastatellut eivät joitakin yksittäisiä mainintoja lukuun ottamatta kiinnittäneet huomiota asiaan.

\section{YHTEENVETO JA POHDINTA}

Yhteenvetona ja täydennyksenä aiemmin esitettyyn voidaan sanoa, että elämäkerta-aineiston valossa suomalainen tapa 'kouluttautua' aktiiviseksi kansalaiseksi näyttää perustuvan perinteisten ja nykyaikaisten ratkaisujen yhdistämiselle:

- kodin huomattava sosiaalistava merkitys,

- koulun ambivalenssi rooli (oppiaineet kuten kansalaistaito, yhteiskuntaoppi, historia vs. erityisesti nuoremman ikäkohortin haastateltujen turhautuneisuus),

- nuorten harrastustoiminnan tärkeys: erilaiset urheiluharrastukset (erityisesti joukkuelajit kuten jääkiekko ja jalkapallo, vaikka kaikki urheilulajit antavat kokemuksia ryhmässä toimimisesta sekä opettavat arvoja korostaessaan esim. reilun pelin tärkeyttä - ja joskus epäilemättä myös päinvastaisia asioita), partio, 4H-toiminta, musiikki, rooli- ja fantasiapelit, tietokonekerhot ja erilaiset virtuaaliset foorumit,

- rippikoulu ja seurakuntatoiminta,

- laaja (joskus anarkistinen) luontoaktivismi nuorempien haastateltujen keskuudessa johtaen toisinaan mahdollisesti myös laittomaan kansalaistottelemattomuuteen,

- vapaan sivistystyön koulutustarjonnan tehokas hyödyntäminen erityisesti vanhemman ikäkohortin keskuudessa (esim. kansalaisopistojen kurssit ja opintokerhot, aiemmin opintopiirit), - opiskelu yliopistossa tai avoimessa yliopistossa,

- ministeriöiden ja muiden viranomaisten tarjoamien uusien tiedonsaanti- ja osallistumismahdollisuuksien hyödyntäminen,

- internetin keskusteluryhmät ja foorumit erityisesti nuorten haastateltujen keskuudessa, - kansainvälisten kontaktien ja yhteyksien hyö- 
dyntäminen erityisesti nuorempien haastateltujen keskuudessa.

Kodin ja varhaisen kasvuympäristön merkityksen korostuminen oli pitkälti odotettavissa tulos. Näyttääkin vahvasti siltä, että aktiiviseksi kansalaiseksi sosiaalistutaan varmimmin seuraamalla lähietäisyydeltä lapsesta asti aktiivisten kansalaisten toimintaa ja osallistumalla siihen. Kysymys on monimutkaisesta yhteiskunnallisesta toiminnasta, jota ei voi omaksua pelkästään oppimateriaaleja hyödyntämällä. Aktiivisen kansalaisuuden oppiminen ja muotoutuminen näyttää lisäksi olevan tiukasti kiinnittynyt ihmisen omaan elämänkulkuun eli aikaisemmin tapahtuneella on vaikutusta myöhäisempään (sekventiaalisuus) ja aikaisemmilla ratkaisuilla on vaikutusta myöhempiin (kumulatiivisuus) (vrt. Tuomi ym. 1999). Toisaalta aineiston perusteella näyttää myös ilmeiseltä, että haastatelluilla on ollut poikkeuksellisen paljon 'pelisilmää' eli kykyä pitää kiinni omista tavoitteistaan ja toiveistaan (Arola/Hoikkala 2000, 4). Elämäkerroissa vastoinkäymiset ja epäonnistumisetkin käännettiin usein voitoiksi ja selviytymistarinoiksi. Näin ollen haastateltujen elämäkertoja voitaisiin lukea myös 'suomalaisina sankaritarinoina', kertomuksina onnistuneesta toimijuudesta (Elder 1997) tai menestyksekkäästä elämänpolitiikan (Giddens 1991, 214) harjoittamisesta.

Aineistossa aktiiviseksi kansalaiseksi tuleminen näytti noudattavan myös eräänlaista duaalimallia: osalle haastatelluista aktiivinen kansalaisuus oli ikään kuin suoraa perintöä lapsuudenkodista ja nuoruuden harrastuksista, kun taas osa oli tullut aktiiviseksi kansalaiseksi vasta aikuisiällä jonkin ulkoisen tai sisäisen haasteen ilmestyttyä elämään. Löydöksellä on yhtymäkohtia Antikaisen $(1997,169)$ - ei aktiivista kansalaisuutta vaan elinikäistä oppimista käsitelleen - elämäkertatutkimuksen tuloksiin:

"Osalla ikäluokkaa on tavoitteenaan polku, joka merkitsee elinikäistä oppimista. Mikäli heille karttuu elämänkulun edetessä sellaisia oppimiskokemuksia, jotka kannustavat jatkamaan tällä polulla, elinikäinen oppiminen muodostuu osaksi heidän elämäntapaansa. Niille nuorille, jotka eivät jo lapsuusvuosinaan suuntaudu elinikäisen oppimisen polulle, on tarjolla aikuiskoulutuksen tarjoama toinen tai toiset mahdollisuudet. Niistä tietoiseksi tuleminen näyttää kuitenkin edellyttävän joko ulkoisen pakon - esimerkiksi per- hesuhteiden muutoksen tai sairauden - tai sisäisen haasteen - esimerkiksi halun haastavampaan tai mielekkäämpään työhön - ilmaantumista elämään”.

Nyt esitelty tutkimushanke on ollut luonteeltaan soveltavaa tutkimusta. Sen vuoksi aineistojen pohjalta on koko ajan käyty keskustelua siitä, miten aktiiviseksi kansalaiseksi kasvamista voitaisiin tukea. Edellä esitetty ei vielä tarjoa perusteluja uudistusehdotuksille vaan tyytyy lähinnä kuvaamaan olemassa olevaa tilannetta. Esimerkiksi edellä mainittua aktiiviseksi kansalaiseksi tulemisen duaalimallin näkökulmasta koulutukselliset haasteet liittyvät yhtäältä siihen (vrt. Antikainen 1997, 171, myös Giddens 1995), miten aktiivinen kansalaisuus - elämäkerran tavoin - saadaan pysymään käynnissä. Toisaalta kysymys on siitä, miten ihmisille tarjotaan yhä uusia mahdollisuuksia tulla aktiivisiksi kansalaisiksi.

Muodollisen koulutuksen osalta tulokset viittaavat siihen, että koulujen opetus ja oppisisällöt vaikuttavat vain vähän aktiivisuustietoisuuden syntyyn ja vakiintumiseen. Tämän perusteella kaksi kehittämissuuntaa saattaisi osoittautua hyödyllisiksi:

1. Koulun osuutta aktiivisen kansalaisuuden kehittymiseen kannattaisi ilmeisesti selvittää tutkimusprojekteissa, jotka kattavat kaikki koulumuodot päivähoidosta kolmannelle asteelle ja aikuiskasvatukseen.

2. Aktiiviseen kansalaisuuteen tähtäävän koulutuksen tavoitteet, sisällöt ja toimintamuodot on todennäköisesti syytä suunnitella kokonaan uudelta pohjalta. Nykyisen tietopainotteisen, ylioppilaskirjoitusten reaalikokeen tapaiseen osaamiseen tähtäävän opetuksen tilalle tarvitaan oppilaiden omaehtoiseen toimintaan perustuvaa, paikallisiin yhteisöihin ja kansalaisaloitteisiin kytkeytyvää ongelmakeskeistä oppimista.

On yleisesti tunnettu tosiasia, että osallistumisella ja aktiivisuudella on taipumus kasautua. Tästäkin huolimatta tuntuu hieman yllättävältä, että haastatellut aktiiviset kansalaiset olivat lähes poikkeuksetta erittäin aktiivisia myös elinikäisinä opiskelijoina. Onkin mahdollista, että aineisto on tältä osin vinoutunutta eli haastateltaviksi valikoitui poikkeuksellisen koulutettuja ja koulutusmyönteisiä henkilöitä. Toisaalta aktiivisen kansalaisuuden ja opiskelu-uran paralleelisuus elämänkulussa tuntuu myös hyvin uskottavalta. Toinen jossain määrin yllättävä seikka liittyi siihen, että huomattava osa haastateltujen 
aktiivisten kansalaisten opinnoista oli luonteeltaan yleissivistäviä tai harrastuspainotteisia. Tältä pohjalta voisi esittää varovaisen hypoteesin, jonka mukaan näennäisen tarpeetonkin opiskelu saattaa hieman pitemmällä aikavälillä osoittautua aktiivista kansalaisuutta tukevaksi toiminnaksi. Tämä ei tietenkään sulje pois sitä, että olisi hyvä, jos yhteiskunnallista ja ehkä myös aikuiskasvatuksellista oppiainesta olisi tarjolla lähes 'JOTperiaatteella' sitä tarvitseville.

Jatkossa aktiivista kansalaisuutta saattaisi olla hedelmällistä tarkastella suhteessa sosiaaliseen pääomaan, kumulatiiviseen kapasiteettiin työskennellä yhdessä yhteisten päämäärien hyväksi (Edwards 1999), jonka on esitetty antavan etua toimijoille yhtä hyvin sekä yksilön (Burt 1992), ryhmän (Coleman 1988) että yhteiskunnan tasolla (Putnam 1993). Lähtökohtana voisi tällöin olla hypoteesi, jonka mukaan aktiiviseksi kansalaiseksi tuleminen edellyttää sosiaalista pääomaa. Toisaalta on myös ilmeistä, että virta kulkee toiseenkin suuntaan: on vaikeaa kuvitella korkean sosiaalisen pääoman yhteisöä, jossa ei ole jäseniä, jotka aktiivisesti osallistuvat ja tukevat yhteisön toimintaa, edistävät yhteistä hyvää. Lisäksi sosiaalisen pääoman ja aktiivisen kansalaisuuden omaksuminen sekä molempien asioiden potentiaaliset edistämisen keinot näyttäisivät noudattavan samantyyppisiä 'lainalaisuuksia': sukupolvelta toiselle ja ylisukupolvinen kulttuurinen välittyminen, toiminnassa oppiminen, vapaaehtoisuus, dialogi jne. (Niemelä 2002a, 87-88). Ovatko aktiiviset kansalaiset itse asiassa sosiaalisen pääoman kantajien ja välittäjien ydin vai miten asiaa pitäisi ymmärtää (vrt. Niemelä 2002b)?

Tässä artikkelissa on keskitytty kuvaamaan, kuinka aktiiviseksi kansalaiseksi kasvaminen tapahtuu elämäkertojen valossa. Sen sijaan itse aktiivinen kansalaisuus on jäänyt vähäiselle huomiolle. Jatkoa ajatellen myös aktiivisen kansalaisuuden sisältöön ja siihen, mitä aktiiviset kansalaiset tekevät tulisi kiinnittää huomiota. Erityisesti tulisi selvittää, mitä aktiivinen kansalaisuus tarkoittaa esimerkiksi työelämässä tai perhepiirissä ja onko ylipäätään järkevää venyttää aktiivisen kansalaisuuden käsitettä kansalaisyhteiskunnan ja järjestöaktiivisuuden ulkopuolelle: mikä tahansa aktiivisuushan ei ole aktiivista kansalaisuutta. Näyttää kuitenkin siltä, että selvät ja erottavat rajat valtion, markkinoiden ja kansalaisyhteiskunnan väliltä ovat sulautumassa yhteen ja että erilaiset yksilölliset lähestymistavat lisääntyvät perinteellisten organisaatioiden kustannuksella (Horsdal 2002).

Lopuksi lienee paikallaan kiinnittää huomiota vielä kahteen tutkimuksen validiteetin arvioinnin kannalta keskeiseen asiaan. Ensinnäkin tutkitut valittiin jo aiemmin esiteltyjen ikä-, sukupuoli-ja kontekstikriteerien perusteella. Keskittymällä kahteen ikäkohorttiin (25-40-vuotiaisiin ja 55-70-vuotiaisiin) pyrittiin saamaan näkyviin Euroopassa mahdollisesti tapahtunut muutos aktiivisen kansalaisuuden oppimisessa. Samalla kuitenkin rajattiin pois sodan jälkeen syntyneet suurten ikäluokkien edustajat, mikä on ongelmallista ainakin Suomen kontekstissa. Jatkossa olisi hyvä haastatella edes joitakin tämän ikäkohortin edustajia ja verrata heidän elämäkerroistaan piirtyvää kuvaa aktiivisesta kansalaisuudesta tähän mennessä kerättyyn aineistoon. Toinen pohtimisen arvoinen asia liittyy haastateltavien valintaan, joka tapahtui tutkimuksen neuvoa antavan asiantuntijaryhmän esiin nostamista ehdokkaista. Näin ollen myös tutkimuksen validiteetti on pitkälti heidän 'kentän tuntemuksensa' varassa. Vain jos oletamme, että haastatelluiksi valikoituneet henkilöt edustavat suomalaisen aktiivisen kansalaisuuden ydintä, tutkimus on voinut kertoa oleellisia seikkoja suomalaisesta aktiivisesta kansalaisuudesta ja sen oppimisesta.

\section{LÄHTEET}

Antikainen, A. (1997). Elinikäisen oppimisen käytännöt ja elämänpolut. Aikuiskasvatus 3, 164-172.

Arola, P. (2000). Tommi Hoikkala pohtii valintojen uutta avaruutta: elämänpolitiikka edellyttää pelisilmää.. Nuorisotyö 1, 2-5.

Aristoteles (335-323 / 1991) Politiikka.. Suomentanut A. Anttila. Jyväskylä: Gaudeamus / Classica-sarja, Aristoteles VII.

Barnes, C., Mercer, G. ja Shakespeare, T. (1999). Exploring disability. A sociological introduction. Cambridge/Oxford: Polity Press.

Benn, R. (2000) The genesis of active citizenship in the learning society. Studies in the Education of Adults 2, 241-256.

Bron, A. (1998) The Changing Agenda on Research in the Education of Adults and the Issue of Citizenship: an Overview. Teoksessa Bron, A., Field, J. and Kurantowicz, E. 
(Toim.) Adult Education and Democratic Citizenship II. Krakow: Impuls Publisher.

Burt, R. (1992). Stuctural holes: the social stucture of competition. Cambridge: Harvard University Press.

Celis, R., Snick, A., Stroobants, V. and Wildemeersch, D. (2001) Introduction. In Celis, R., Snick, A., Stroobants, V. and Wildemeersch, D. (ed) Learning Citizenship and Governance in Europe: Analysis of Life Histories. Framework 5 funded Project Report submitted to the Commission of the European Communities, Leuven: Catholic University of Leuven, Belgium. Available HTTP: http://www. surrey.ac.uk/Education/ETGACE/Lifehistory-chapter3.pdf (4 July 2002).

Coleman, J. S. (1988). Social capital in the creation of human capital. American Journal of Sociology 1, 95-120.

Crick, B. (2000) Essays on Citizenship. London: Continuum.

Delanty, G. (2000) Citizenship in a global age. Buckingham/Philadelphia: Open University Press.

Edwards, M. (1999). Enthusiasts, Tacticians and Sceptics: The World Bank, Civil Society and Social Capital. Saatavana HTTP: http:// www.worldbank.org/poverty/scapital/library/ edwards.pdf(17.2.2003)

Elder, G. Jr. (1997). The Life Course as Developmental Theory. Presented at the biennial meeting of the Society for Research in Child Development, Washington DC, April 5, 1997. Saatavana HTTP: http://www.cpc.unc.edu/ pubs/presentations/srcd-97.htm (6.2.2003).

Giddens, A. (1991). Modernity and Self-Identity. Cambridge: Polity Press.

Giddens, A. (1995). Elämää jälkitraditionaalisessa yhteiskunnassa. Teoksessa Beck, U., Giddens, A. ja Lash, S. Suomentanut, Lehto. L. Nykyajan jäljillä. Tampere: Vastapaino.

Goodson, I. ja Sikes, P. (2001). Life History Research in Educational Settings. Learning from Lives. Buckingham/Philadelphia: Open University Press.

Gordon, T. ja Lahelma, E. (1998). Kansalaisuus, kansallisuus ja sukupuoli. Teoksessa Alasuutari, P. ja Ruuska, P. (Toim.) Elävänä Euroopassa. Vastapaino.
Harju, A. (2002). Yhteisellä asialla. Kansalaistoiminta ja sen haasteet. Kansanvalistusseura.

Heater, D. (1999). What is Citizenhip? Cambridge: Polity Press.

Horsdal, M. (2002). Description of the Competencies Related to Active Citizenship. Puheenvuoro 'Active Citizens - Active Learning. Implications for Research and Policy' konferenssissa 15-16.3.2002.

Jarvis, P. (2001). Active Citizenship and Lifelong learning. Teoksessa Korsgaard, O., Walters, S. ja Andersen, R. (Toim). Learning for Democratic Citizenship. Association for World Education and the Danish University of Education.

Jarvis, P. (2002). Active Citizenship and the Learning Society. Lifelong Learning in Europe 1: 19-27.

Jääskeläinen, P. (2000) Ovatko työttömien ja työllisten käsitykset kansalaisuudesta erilaisia? Politiikka 2, 116-126.

Koistinen, P. (1999). Työpolitiikan perusteet. WSOY.

Korsgaard, O. (2001, 67) The Struggle Regarding Citizenship. From Social Citizenship to Active Citizenship. From Adult Education to Lifelong Learning. Teoksessa Korsgaard, O., Walters, S. ja Andersen, R. (Toim). Learning for Democratic Citizenship. Association for World Education and the Danish University of Education.

Korsgaard, O. (2002). The Dimensions of Active Citizenship. Alustus VSY:n ja YLE:n Aktiivinen kansalaisuus -työseminaarissa 18.3.2002. Saatavana HTTP: http:// www.vsy.fi/vsop/aktkansove.htm (27.2.2003).

Kymlicka, W. (2002) Contemporary Political Philosophy. Oxford: Oxford University Press.

Laitinen, M. ja Nurmi K. E. (2002). Biographical observations on active citizenship learning in Finland. University of Helsinki, Department of Education, Research report 183.

Lappalainen, S. (2002). ”Eskarissa eurokuntoon" -esiopetus (suomalais)kanssallisena projektina. Teoksessa Gordon, T., Komulainen, K. ja Lempiäinen, K. (Toim.) Suomineitonen hei! Kansallisuuden sukupuoli. Tampere: Vastapaino.

Lawson, H. (2001) Active citizenship in schools 
and the community. The Curriculum Journal 2, 163-178.

Marshall, T.H. (1950). Citizenship and Social Class and Other Essays. Cambridge: Cambridge University Press.

Niemelä, S. (2002a). Kansansivistyksen kadottaminen. Aikuiskasvatus 2, 84-91.

Niemelä, S. (2002b). Sosiaalinen pääoma, aktiivinen kansalaisuus ja aikuiskoulutus vuoteen 2010. Esitelmä 'Aktiivinen kansalaisuus ja hyvä hallinto Suomessa ja Euroopassa' asiantuntijaseminaarissa 24 toukokuuta 2002.

Perczynski, P. and Vink, M. (2002) Citizenship and Democracy: A Journey to Europe's Past. Citizenship Studies 2, 183-199.

Putnam, R. (1993). Making Democracy Work. Civic Traditions in Modern Italy. Princeton: Princeton University Press.

Sihvola, J. (1991). Selitykset. Teoksessa Aristoteles (335-323 / 1991) Politiikka.. Suomentanut A. Anttila. Jyväskylä: Gaudeamus / Classica-sarja, Aristoteles VII.
Tuomi, J. ja Elämänkulkutyöryhmä (1999). Elämänkulku ja terveys: katsaus teorioihin ja sovelluksiin: raportti II. Saatavana HTTP: http://www.skuwwa.fi/KTNK/tk21/elama/ raport2.htm (6.2.2003).

Walters, S. and Watters, K. (2001) 'Lifelong learning, higher education and active citizenship: from rhetoric to action', International Journal of Lifelong Education 6, 471478.

Yuval-Davis, N. (1997). Gender and Nation. London: Sage.

\section{VIITE}

Suomalaisessa tutkimuksessa olemme tavallisesti käyttäneet neuvoa antavasta asiantuntijaryhmästä, englanniksi 'advisory panel' nimitystä johtoryhmä.

Artikkeli saapui toimitukseen 8.3.2002. Se hyväksyttiin julkaistavaksi toimituskunnan kokouksessa 3.3.2003. 